\title{
MIT SREDNJE EVROPE V LITERARNEM DISKURZU 20. STOLETJA
}

Ključne besede: mit, srednja Evropa, minimalistični in maksimalistični koncept

V našem razmišljanju ne gre za izčrpen pregled posameznih konceptov srednje Evrope v literarnovednem, kulturnem ali politološkem diskurzu, ampak bolj za navajanje temeljnih problemov in oris njihovih zgodovinskih, literarnih in geopolitičnih povezav. Zapletenost terminologije in semantike, povezane s študijem srednje Evrope, je zahtevala kopico bibliografskih enot, nepregledno vrsto študij in besedil, v katerih se lahko le s težavo orientiramo ali iščemo interdisciplinarne povezave. Srednja Evropa se je realno spreminjala $\mathrm{v}$ času in prostoru, horizontalno in vertikalno, pa tudi v svojem strukturnem temelju. Jasno je, da srednjeveškega razumevanja srednje Evrope ne moremo povezovati npr. z romantičnim nacionalizmom 19. stoletja, prav tako pa so zgodovinski mejniki 20. stoletja, npr. leta 1918, 1945 ali 1989, radikalno zanikali predhodno splošno pojmovanje, kaj specifično je ta regija prinesla v kulturo, vedo in politiko in kaj je mogoče v prihodnje pričakovati od nje. Drugače bodo svoje razumevanje definirali in zagovarjali politiki, ekonomisti, geografi, zgodovinarji ali umetnostni teoretiki, težko bodo skupni jezik našli jezikoslovci in muzikologi ali arhitekti pri vprašanju, kakšne so splošno veljavne poteze ideologemov srednjeevropejstva, kje se začenjajo in kje končujejo njihove meje ter ali je sploh mogoče v znanstvenem diskurzu problem tako zastaviti. Slovenski literarni teoretik Janko Kos (1990) govori o temeljnih razlikah med literarnovednim, kulturnozgodovinskim in političnim razumevanjem, ki se praviloma ne prekriva z zemljepisno zamejitvijo srednje Evrope. Kljub tem omejitvam fenomen srednje Evrope, ki se večinoma manifestira ideološko 
in politično ter hkrati to mejo pogosto presega $\mathrm{v}$ smeri proti kulturi, umetnosti, pa tudi sociologiji, filozofiji, semiotiki ter sorodnim vedam, ostaja vznemirljiv intelektualni konstrukt, ki nekaj pove o nas samih, tj. o virih naše identitete in koreninah evropske civilizacije.

Za srednjo Evropo kot kulturni in geografski prostor oziroma križišče med Zahodom in Vzhodom je bila vedno značilna spremenljiva pozicija nestabilnih centrov in periferij, specifično prepletanje etnosov, kultur in verstev. $\mathrm{V}$ splošno razširjenem publicističnem in politološkem diskurzu je mogoče - z zavestnim poenostavljanjem - razlikovati dva koncepta srednje Evrope: minimalističnega in maksimalističnega (Kontler, 2000, 10-11). Minimalistični koncept ima ta prostor za zadnji »rt «Zahoda glede na skupne zgodovinske strukture in kulturne vrednote; srednjeevropejstvo tu postaja elitna civilizacijska drža, ki skozi zahodnoevropsko optiko opazuje razvojno »zapozneli« Balkan in Rusijo, tj. južni in vzhodni del Evrope. ${ }^{1}$ Minimalistični koncept uporablja binarne opozicije, kot jih je definiral francoski dekonstrukcijski filozof Jacques Derrida (mi : oni, naše : tuje, civilizacija : barbari), $\mathrm{z}$ mitom centra in periferije, meja in konca Evrope, ki prispeva $\mathrm{k}$ dihotomičnemu (dualističnemu) razumevanju srednje Evrope. Tako jo razume tudi Milan Kundera, ki je sredi 80. let ta prostor definiral kot specifično regijo malih narodov med Nemčijo in Rusijo, ki kulturno sodi k Zahodu, politično pa je (od leta 1945) priključen Vzhodu. ${ }^{2}$ Maksimalistični koncept srednjo Evropo razume predvsem aksiološko, geografski konstrukti so tukaj stranski produkt in sam obstoj središča Evrope je postavljen pod vprašaj prav tako kot včasih namerno členjenje Evrope na posamezne dele. Evropa, torej tudi njen srednji del, se profilira kot skupek zgodovinsko nastalih idej, večinoma povezanih $s$ tradicijo latinskega krščanstva, ki omejujejo odnos stare celine kot celote do sosednjih celin, zlasti do Azije, iz katere je Evropa, kot pogosto radi pozabimo, civilizacijsko izšla. Madžarski zgodovinar László Kontler to tezo konkretizira: "[...] poleg gledanja na srednjo Evropo kot na utopijo [...] obstaja srednja Evropa v pojmih, ki jih je mogoče podvreči objektivni analizi [...] delitev moči med krono in privilegiranimi stanovi ali

1 Dorovský, Ivan (1997) Balkán a Mediterán. Brno.

2 Kundera, Milan (1984) „Zachód porwany albo tragedia Europy środkowej.“ Zeszyty Literackie 5 . 
redovi, legalno vzpostavljena fevdalna hierarhija, svobodna mesta in delitev dela med njimi in njihovo kmečko okolico, viteška kultura, renesančni humanizem in reformacija [...] "(Kontler, 2000, 11-12.)

Čeprav srednja Evropa v maksimalističnem konceptu nima strogih meja in trdne oblike, je jasno, da se bolj primika $\mathrm{k}$ Zahodu, v katerega se vključuje kot njegov integralni, vendar zapozneli in manj razviti del, a kljub temu del, v katerem se je v nasprotju z muslimansko ali bizantinsko civilizacijo odigraval "razvojni vidik prodora zahodnih struktur na vzhod" (Kontler, 2000, 12). S stališča filozofije zgodovine se do maksimalistične srednje Evrope na zanimiv način izreka češki teolog Břetislav Horyna: ne gre samo za geopolitično kategorijo, srednja Evropa je tudi paradigma, znak, stil, tema, v bistvu nekakšen metaforični poziv in vprašanje, ki si ga nenehno zastavljamo, vendar pa nanj nismo zmožni prepričljivo odgovoriti (Horyna, 2001, 9). Kategorično to pojmovanje razdela tudi češki publicist Josef Kroutvor (1990), ki sodi, da srednja Evropa kot politični fenomen ne obstaja, ker je po drugi svetovni vojni razpadla na Zahod in Vzhod. Nasprotni nazor pa oblikuje češki politik in filozof Petr Pithart, ki dokazuje, da je srednja Evropa prej politično omejena kategorija kot pa kulturni pojem že samo zato, ker je geografski prostor med Zahodom in Vzhodom, zapolnjen s slovansko-germanskim etnosom, doživel skupno zgodovinsko usodo in predstavljal - ne glede na politične skrajnosti - relativno centralizirano administrativno in ekonomsko ozemlje, katerega "povezovalec ni bila toliko ujemajoča se družbena ureditev, ena sama cerkvena institucija in skupni literarni ter sporazumevalni jezik, ampak predvsem enoten način življenja, enotna izobraženost, enako veljavna lestvica priznanih vrednot" (Podiven, 2003, 34). Srednja Evropa v tem smislu sodi k Zahodu in z njim zlasti v srednjem veku tvori »določeno enotnost v raznolikosti« (Podiven, 2003, 34), ki jo danes označujemo kot »krščansko Evropo«, rojeno na temeljih svetega rimskega cesarstva: "Živo telo Evrope je bilo takrat organsko organizirana struktura. Slutiti je bilo nekakšno sredino $v$ prostorskem, oblastniškem in duhovnem smislu." (Podiven, 2003, 34.) Madžarski politolog romunskega porekla G. Molnár pokaže na geografske in zgodovinske premene v razumevanju srednje Evrope, ki nikoli v zgodovini ni nastopala kot avtonomna politična enota, ampak kot obrobna, mejna cona zahodne civilizacije, razprostirajoče se na ozemlju nekdanje države Karla Velikega: 
»Ta Karlov svet, ki se ... razprostira od Toulousa do Brna, je temelj zahodne Evrope kot zgodovinskega organizma $z$ enotno strukturo. In to je svet, $v \mathrm{ka}-$ terem sta Madžarska in Poljska, ti dve srednjeevropski državi par excellence, vedno ostali zunaj. Srednja Evropa sodi - že tisoč let - v zahodno civilizacijo, vendar pa ni del zahodne Evrope, razumljene kot zgodovinsko-politični, enotno organiziran korpus po Karlovem modelu. (Molnár, 2006, 168)

Če se vrnemo k minimalističnemu razumevanju, njegove korenine segajo globoko v srednji vek, ko se je srednja Evropa zlivala s podonavsko monarhijo, ki se je definitivno formulirala v 17. stoletju kot obrambna zveza narodov proti turški nevarnosti (npr. zmaga nad Turki 1683 pri Dunaju); podobno naj bi bila v 19. stoletju habsburška država branik pred rusko ekspanzijo na Zahod. Od tod so izvirali strahovi pred razpadom Avstro-Ogrske kot stabilizirajočega dejavnika za srednjeevropsko ravnotežje (F. Palacký). Teoretično je ta koncept izrazil pruski militarist Friedrich Naumann (1915) med prvo svetovno vojno kot del nemške vojne propagande, ki si je prizadevala za nastanek srednjeevropske monarhije pod nadvlado Nemčije. Še konec 20. stoletja je francoski zgodovinar in publicist madžarskega porekla François Fejtö izrazil obžalovanje nad dejstvom, da je razbitje Avstro-Ogrske pomenilo katastrofo za politično zgodovino srednje Evrope in da "posledice čutimo še danes" (Fejtö, 1998, 6), tj. če ne bi bilo subjektivnega razbitja, in ne zakonitega razpada habsburške monarhije, ne bi bilo niti Jalte in sovjetizacije srednjeevropskega prostora oziroma v začetku 90. let npr. delitve Češkoslovaške ali krvavega spopada med narodi nekdanje Jugoslavije. Za Fejtöja je srednja Evropa »simbol izgubljene priložnosti (Fejtö, 1998, 250), še zlasti zato, ker je leta 1918 dala prednost nacionalistom, ne pa federalističnemu modelu reševanja medsebojnih političnih odnosov. Čeprav francoski zgodovinar povsem zanemari naravno pravico do samoodločitve malih slovanskih narodov kot logični iztek dolgoročnih zgodovinskih, državotvorno-emancipacijskih procesov v tem prostoru, je relativno natančno zajel skozi stoletja nastajajoč in še danes živ občutek srednjeevropske zavesti, ustvarjene na ozemlju habsburške monarhije, nekakšne srednje Evrope v malem, ki je predstavljala ekonomsko in administrativno enotno ozemlje $\mathrm{z}$ visoko stopnjo urbanizacije in pravim križiščem narodov s pestro kulturo. Avstro-Ogrska je tako utelešala sociokulturni prostor z močno nadnarodno solidarnostjo (pa tudi sovraštvom), kjer se je izoblikoval tip 
človeka »homo habsburgiensis«, katerega »senzibilnost in mentaliteta sta bili drugačni kot pri velikih narodih Zahoda in Vzhoda, Francozih, Nemcih, Angležih in Rusih« (Fejtö, 1998, 250).

Če je bila »nemška varianta« tega koncepta, ki je izhajala iz nazora pruskega militarista Naumanna, agresivnejša in bolj politično poudarjena njena kompromitacija je dosegla vrhunec s Hitlerjevim pristopom $\mathrm{k}$ rešitvi t. i. vzhodnega prostora (Ostraum) -, je bila »avstrijska« srednja Evropa tudi po razpadu Avstro-Ogrske stvar intelektualne razprave, ki so jo že v 80. letih razvneli intelektualci, večinoma emigranti in disidenti iz srednjeevropskih držav: temeljno vlogo je pri tem odigral esej Milana Kundere Ugrabitev Zahoda (Únos Západu), objavljen v angleščini pod naslovom Tragedija srednje Evrope (The Tragedy of Central Europe, 1984), ki poudarja dvom glede oblastniških in ideoloških rešitev državnopravne ureditve srednje Evrope, ki nima trdnih geopolitičnih meja in je bolj mesto srečevanja, dialoga in soobstoja, analogičnega kulturnega spomina in zgodovinske izkušnje. Besedila npr. V. Havla, G. Konrada, C. Miłosza pritrjujejo srednjeevropski identiteti kot določeni duhovni tradiciji, ki zanika geopolitično realnost po letu $1945 .^{3}$

Če ostanemo pri Kunderovem besedilu (1985), je njegov pomen v tem, da je razpravo o srednji Evropi iz politološkega diskurza vrnil na literarnofilozofsko raven in da so njegova razmišljanja, ne glede na to, ali so zbujala soglasje ali zavračanje, postala izhodiščna refleksija, mimo katere ni mogoče. Čeprav pri Kunderi prepoznamo skrito nostalgijo za izgubljeno duhovno atmosfero habsburške monarhije, najdemo pri njem tudi strogo zanikanje »nemške« variante srednje Evrope. Ta sama po sebi geopolitično ne obstaja več, nima čvrstega jedra niti meja; njihovo spremenljivost in imaginativnost je mogoče teritorialno omejiti z znakom skupne zgodovinske usode, analogičnim odnosom do skupnih kulturnih vrednot, ki jih ustvarjajo mali narodi, živeči $\mathrm{v}$ nedoločnem prostoru med Nemčijo

3 Gre za besedila V. Havla Anatomie jedné zdrženlivosti (1985), G. Konrada Antipolitika (Antipolitics, 1984) in C. Miłosze Svědek poezie (The Wittnes of Poetry, 1983). Ta besedila podrobno interpretira Balabanová, Christina (2004) „Stredná Európa a stredoeurópsky geografický kultúrny priestor (S prihliadnutím na interpretácie Milana Kunderu, Györgya Konrada, Václava Havla, Czeslawa Miłosza)." V: Hrdina v stredoeurópskych a balkánskych literatúrach 19. a 20. storočia. Bratislava. 9-19. 
in Rusijo. Mali narodi niso bili nikoli osvajalci, njihov obstoj je bil vedno odvisen od volje mogočnih sosedov, mali narod se je vedno zavedal, da lahko izgine. Etnično predstavlja srednja Evropa zapleteno mnogonarodno slovansko-neslovansko mešanico, vključno s samostojnim židovskim elementom, ki simbolizira tragično izkušnjo srednjeevropskega intelektualca. Ideal geopolitične in duhovno-družbene ureditve srednje Evrope Kundera pravzaprav poistoveti, identificira s federativnim modelom, $\mathrm{z}$ demokratično družbo malih kulturno univerzalnih narodov; ta nadnarodna celovitost pa ne izloča enkratnosti posameznih enot - lokalnih centrov, ki bogatijo skupno dediščino. Srednja Evropa je vedno opravljala funkcijo »mosta in povezovalnega koridorja - v tem se Kundera prosto navezuje na avstroslavistični čut F. Palackega in Masarykove predstave o strateški funkciji srednje Evrope, nekakšne simbolične osi, ki zagotavlja stabilnost evropskega varnostnega sistema po prvi svetovni vojni. Po Kunderovem mnenju mora ravno srednja Evropa s svojim centralnim položajem "srca« v evropskem telesu uravnavati zahodne (moč tehnologije) in zlasti vzhodne skrajnosti (sovjetski totalitarizem). Zato ne preseneča, da Kundera Rusijo zaradi njene nedemokratične preteklosti iz Evrope izključuje. Kot razločevalni potezi srednjeevropskosti Kundera navaja skepticizem in (samo)ironijo, ki omogočata preseganje eksistencialnega dvoma o »veliki« zgodovini in predvsem nezaupanja v lastno majhnost. Ti prvini Kundera najde neposredno zakodirani $v$ številnih avtorskih strategijah: $\mathrm{v}$ pripovednih tehnikah, romanesknih strukturah in umetnostnih oblikah pri tipično srednjeevropskih pisateljih in umetnikih (B. Bartók, H. Broch, W. Gombrowicz, J. Hašek, L. Janáček, F. Kafka, R. Musil, B. Schulz, S. Witkiewicz idr.), o katerih med drugim govori tudi v svojem delu Umetnost romana (Kundera, 1986). Če Kunderova srednja Evropa ne predstavlja geografsko negibnega objekta in nima trdnih meja, saj dinamično, historično spremenljivo združenje malih narodov v zgodovini nikoli ne ostaja enako, podobno tudi njegovemu kolegu Václavu Havlu ne gre toliko za natančno poimenovanje kot za moč idej, za mehanizem delovanja in kriterije, prek katerih se lahko temu problemu približamo. Havel v razpravi Anatomija neke zadržanosti (Anatomie jedné $z d r z ̌ e n l i v o s t i)$ srednjo Evropo pojmuje kot »duhovni, kulturni in mentalni fenomen", ki ga "nenehno oblikujejo specifične zgodovinske izkušnje» (Havel, 1990a, 74). Kot temeljne znake srednjeevropskega psihičnega substra- 
ta v skupnem kulturnem spominu navaja skepso, smisel za ironijo, samoironijo, h kateri sodi tudi črni humor, ter predvsem žanrsko prepletanje komičnih in tragičnih leg $\mathrm{v}$ edinstveno celoto, ki jo v različnih razmerjih najde pri F. Kafki, J. Hašku, R. Musilu ali L. Vaculíku (Češka sanjska knjiga; Český snář). Ravno literatura mora zaradi svojega recepcijskega dosega - v tem pa lahko vidimo neposredno avtorjevo navezavo na prerodno ideologijo, verujočo $\mathrm{v}$ moč besede - postati naravna oblika in ščit zgodovinsko podedovanih arhetipov in drž, kot sta npr. skozi stoletja zakodirani skepsa in nezaupanje $\mathrm{v}$ ideologije in utopične projekte.

Pri Havlu in njegovih intelektualnih kolegih je srednja Evropa razumljena kot mitično kulturno središče, center celotne Evrope, ki ga naseljujejo mali narodi in pretresajo geopolitični interesi velesil. Havel geografsko središče srednje Evrope v nasprotju s Kunderovo predstavo policentričnega in mnogonarodnega kulturno-zgodovinskega prostora s spremenljivimi mejami postavlja $\mathrm{v}$ češke dežele, ki so bile baje vedno križišče najrazličnejših tokov, impulzov in iniciativ. Havlova vizija, ki kritizira razdelitev Evrope $\mathrm{v}$ dva protislovna bloka, postaja ideal demokratično združene Evrope kot prijateljske združbe svobodnih in neodvisnih držav. Očiten je moralni etos državljanske družbe, antropološka perspektiva, filozofsko-zgodovinsko zasidranje, katerega retorika pa se po letu 1989 vendarle nekoliko spreminja. $\mathrm{V}$ političnih govorih, ki jih je v začetku devetdesetih let imel kot predsednik, Havel zdrsne v idealizem, ko ugotavlja, da se danes ponuja priložnost "[...] spremeniti srednjo Evropo, kot do zdaj pretežno zgodovinski in duhovni fenomen, v politični fenomen « (Havel, 1990b, 43). Čeprav ostaja ideja, da Evropa ne bi smela biti skupek držav, narodov, kultur, etnikov in regij, ki živijo drug ob drugem, ampak skupni duhovni prostor, utemeljen na principu odprte družbe (demokracija, spoštovanje človekovih pravic, prosti trg, zasebna lastnina, politični pluralizem ipd.). Vendar se mora ta proces odigrati pod patronatom zahodnoevropskih integracijskih mehanizmov, ki se bodo razširili na srednjo ter kasneje tudi vzhodno Evropo, najbolje v podobi Združenih držav Evrope ali Evropske konfederacije (F. Mitterand). Vstop malih srednjeevropskih narodov v Nato in Evropsko unijo na prelomu drugega in tretjega tisočletja je imel Havel za uresničitev vizije svobodne srednje Evrope: v primeru čeških dežel za simbolično piko po eni od etap stalne diskusije o smislu nacionalne zgodovine. 
S svojo filozofijo antipolitične politike je Havlu blizu tudi nekdanji madžarski disident György Konrad (1985), ki srednjeevropejstvo prav tako povezuje s skeptičnim in samoironičnim načinom mišljenja; poistovetenje $\mathrm{s}$ srednjeevropsko identiteto pomeni predvsem prolongiranje in specifično oblikovanje nacionalne tradicije in kultur, ki so se tisočletja kulturno in politično nagibala $\mathrm{k}$ Zahodu in ki so se $\mathrm{v}$ drugi polovici 19. stoletja razvijale v dualistični Avstro-Ogrski. Če je po letu 1945 tragedijo srednje Evrope povzročila sovjetska hegemonija, v Konradovi argumentaciji srednjeevropskost postaja izraz družbene zavesti, ki je svoj izvor zgodovinsko vedno vezala na Zahod. Podobno poljski pisatelj in dobitnik Nobelove nagrade za literaturo Czesław Miłosz v knjigi esejev Pričevanje poezije (1983) in Srednjeevropska razmišljanja (1986) srednjo Evropo premakne na Vzhod proti Estoniji in Litvi - Miłosz se je namreč v Vilni rodil - mejno črto pa potegne $\mathrm{z}$ upoštevanjem verske razdelitve Evrope na krščansko območje zahodnega latinskega tipa in vzhodno pravoslavje. Srednja Evropa je povsod tam, kjer najdemo neposredno kulturno povezavo $\mathrm{z}$ zahodno antično civilizacijo $\mathrm{v}$ podobi grško-rimske kulturne tradicije. Ta geografsko in idejno presega prostor habsburške monarhije, zajame celo nekdanjo srednjeveško poljsko-litovsko državo (Rzeczpospolita). Mit federativne zveze narodov pod poljsko nadvlado se v poljski literaturi in publicistiki pojavlja pravzaprav že od davnih dob pa vse do danes. Dovolj je, da se spomnimo Sienkiewiczeve umetniške vizije plemiške demokracije Poljakov, Ukrajincev, Belorusov in Litovcev, združenih pod poljsko zastavo. ${ }^{4}$ Miłosz prav tako omenja primere češko-poljskega sodelovanja $\mathrm{v}$ obdobju reformacije in poznega humanizma, tj. v obdobju, ko se je v srednji Evropi počasi uveljavljal univerzalni, čeprav z narodnimi variantami, tipološko enolični baročni slog.

Jasno je, da je Miłosz s svojo odklonilno držo do Rusije in nepripravljenostjo omejiti sredino in meje srednje Evrope bližje Kunderi kot Havlu. To med drugim izhaja tudi iz smisla knjige Rodzinna Europa (Rodna Evropa, 1998), v kateri Miłosz govori o protislovju med "zasebno« (s čimer misli majhno, družinsko Evropo, kjer se je rodil) in »javno« (veliko) Evropo: geografsko obrobje ter realna in mitska sredina Evrope sta tu še bolj poljub-

4 Měštan, Antonín (1992) „Der Mitteleuropäiche Raum in den Literaturen Mitteleuropas nach 1945.“ V: Ferdinand Seibt. München 1992, 369-376. 
na. Srednjeevropejstvo predstavlja simbolično vrednoto, ujeto s pomočjo specifične avtorske strategije, ki ni samo dokumentarna ali avtobiografska, ampak tudi domišljijsko fabulativna: srednja Evropa je genetsko zakodirana $\mathrm{v}$ naših vzorcih obnašanja in modelih komunikacije, to so naši subjektivni spomini, pa tudi realne usode konkretnih ljudi, ki sinekdotično zastopajo peripetije in katastrofe malih zatiranih narodov. Podoben pristop, izhajajoč iz nekakšne kulturne antropologije ali postmoderne mikrozgodovine, zastopa tudi poljski prozaist srednje generacije Andrzej Stasiuk, ki razglaša srednjo Evropo za zasebno, enkratno in živo zgodovino, za subjektivno zgodbo. Ta se lahko odigrava npr. v dialogu med ljudmi, lahko nastopa tudi kot nedefinirana čutna zadeva, ki se $\mathrm{v}$ intencah postmodernizma nenehno ponavlja kot vsakodnevni akt naše komunikacije z okolico. Svet, ki ga osvoji mali nepatetični junak, ki ga intimno pozna in od koder ne more uiti, najdemo tudi pri češkem romanopiscu Bohumilu Hrabalu, katerega "pabitelji« doživljajo travme srednjeevropske identitete: strah, tesnobnost, izkoreninjenost, prizadevanje po spremembi in večno vračanje. Beloruski prozaist Jurij Andruchovič (2001), ki je skupaj z A. Stasiukom napisal esejistično knjigo Moja Europa. Dwa eseje o Europie zwanej Srodkowej srednjeevropejstvo povezuje $\mathrm{z}$ motivom potovanja: zasebne usode ljudi, živečih $\mathrm{v}$ ogromnem prostoru med Nemčijo in Rusijo, sicer deformira velika zgodovina, s katero pa se obrambno soočamo z občutkom, da je kot posamezniki nikoli ne moremo obrniti v svoj prid. Prava srednja Evropa je svet, ki ga intimno poznam, ki nima sredine niti robov, ki se nahaja tam, kamor je mogoče priti, kamor je mogoče seči ali kamor je mogoče videti.

Pogosto se razmišljanja o srednji Evropi v geografski simboliki povezujejo z Donavo kot ločevalnim in povezovalnim elementom. Npr. italijanski germanist Claudio Magris motiv srednjeevropejstva vidi v povezavi s proučevanjem habsburškega mita, $s$ sakralizacijo Donave, ki presega meje srednje Evrope in jo povezuje z Balkanom in območjem Sredozemlja: "Donava, to je nemško-madžarsko-slovansko-romansko-židovska srednja Evropa, ki stoji v ostrem nasprotju z germanskim Reichom, to je 'inter-nacionalna' ekumena, to je svet ' $z a$ narodi'." (Magris, 1992, 24-25.) Donava kot sveta slovanska reka v vsej svoji dolžini - to je meja med Evropo in Balkanom. Medtem ko germanski Ren straži etnično čistost nemštva (spomnimo se tesnobne mistike Wagnerovih oper), Donava pomeni komunikacijo in di- 
alog, prek nje se Nemci in Avstrijci stikajo z zahodnimi Slovani, pa tudi z Madžari in južnimi Slovani ter muslimani in pravoslavno kulturo. Čeprav motiv Donave v povezavi s habsburškim mitom izraža nekakšno nostalgijo po mnogonarodni monarhiji in višji srednjeevropski identiteti, vladajo različni nazori na vprašanje, do kakšne mere je bila srednjeevropskost reflektirana v samem centru monarhije v Avstriji. Medtem ko Magris ostaja skeptičen - srednjeevropskosti nima za "pravo stalnico avstrijske zgodovine« (Magris, 2001, 29) - pa ruski germanist D. Zatonski (1985) govori o donavskem kulturnopolitičnem arealu, v katerem je dominantna Avstrija igrala vlogo mosta, tj. posrednika med nemškim Zahodom in slovanskim Vzhodom oziroma zasedala pozicijo stražarja zahodnoevropskega prostora; dovolj je, da prosto parafraziramo pogosto citirano izjavo avstrijskega kanclerja Metternicha, da se meje Evrope (pri tem je imel v mislih »civilizirano« Evropo) končujejo pred vrati Dunaja. Kot je pokazala ruska slavistka S. Šerlaimová (1993), ta teorija povsem spregleda pomen neposrednih kontaktov zahodnih slovanskih književnosti, ki so v okviru habsburške monarhije ustvarile lastno medliterarno družbo z zapletenim konglomeratom internih in eksternih odnosov. Čeprav so splošne avstrijske realije pogosto prodirale $\mathrm{v}$ tematiko slovanskih, pa tudi madžarskih in romunskih pisateljev, je pogosto šlo le za zunanji okvir, odločilna je bila izbira jezika kot definirajočega distinktivnega koda, tega pa so slovanski pisatelji od časov narodnega preroda izbirali večinoma na osnovi svojega etničnega porekla. Inspirativni nauk lahko najdemo na jezikoslovnem področju, v teoriji jezikovnih povezav oziroma arealov, utemeljenih na analizi geografskih povezav tipoloških lastnosti jezikov (tudi strukturno nesorodnih), ki soobstajajo v bližnjem sosedstvu. ${ }^{5}$ Številni vplivi in kontakti medsebojno bogatijo jezike, ki pa vendarle ohranjajo avtohtonost zgodovinskega razvoja. Sodobno jezikoslovje govori npr. o srednjeevropskem jezikovnem arealu oziroma o širšem donavskem arealu, kjer so se stikali in drug na drugega vplivali indoevropski jeziki dveh različnih skupin - germanske in slovanske ter ugrofinske madžarščine - in opozarja na paralelne procese,

5 Kot utemeljitelj jezikovno-arealne tipologije se ponavadi navaja ruski jezikoslovec N. S. Trubeckoj skupaj s češkim strukturalistom ruskega rodu R. Jakobsonom. Njun koncept je izhajal iz prepričanja, da jeziki v geografski bližini komunikacijsko vplivajo drug na drugega do te mere, da se lahko njihove strukturne lastnosti razvijajo skupno. 
na konvergentne tendence na področju glasoslovja, pa tudi oblikoslovja in še zlasti besedišča. ${ }^{6}$

Včasih postaja prepoznavni znak srednje Evrope židovski element: srednja Evropa je baje povsod tam, kjer v Evropi živijo Židje (M. Kundera). Srbski pisatelj Danilo Kiš (1978), ki se strinja s Kundero, gre pri tem še dlje: Židje so v srednji Evropi vedno utelešali premik in spremembo, bili so povezovalni element med malimi evropskimi narodi in so $\mathrm{v}$ največji meri prispevali k multikulturnemu značaju tega dela Evrope. Zgodovina srednje Evrope se je baje končala s prisilnim uničenjem in izgonom Židov, saj njihova tragična usoda zrcali psihično travmo srednjeevropskega intelektualca, ki je bil izkoreninjen iz svoje »rodne« zemlje. Pisatelji židovskega porekla, živeči v srednji Evropi, kot so F. Kafka, B. Schulz, I. Bashevicz, E. Canetti, G. Konrad, S. Marai in drugi, so bili pogosto označevani kot »srednjeevropski« pisatelji. Vendar pa ni nujno, da je srednja Evropa samo židovska, pogosteje je povezana s krščansko tradicijo. Npr. papež Janez Pavel II. je govoril o krščanstvu kot integrirajoči univerzalni vrednoti, ki mora biti predhodnica gospodarsko-političnega povezovanja Evrope. Ravno srednja Evropa je lahko po njegovem mnenju primer medverskega in medkulturnega dialoga ne samo med verujočimi, saj so ravno to nekakšna »dvoja pljuča Evrope«, tu se namreč harmonično prepletata in vzajemno dopolnjujeta vzhodni (Ciril in Metod) ter zahodni latinski obred. ${ }^{7}$ Podobno je eden od njegovih predhodnikov Pavel VI. navajal regule sv. Benedikta kot prvi pisani dokument, ki razglaša evropsko ustavo in zahteva, da Evropejci ohranijo skupni, tj. krščanski način življenja. ${ }^{8}$ Češki teolog in filozof O. A. Funda (2000) navaja, da med vire sodobne evropske civilizacije sodita ne samo židovstvo in krščanstvo, ampak tudi antika in pozneje laični humanizem. Vprašanje, ali ima Evropa religiozne ali posvetne korenine, zato ostaja

6 Prim. Newerklá, Stefan Michael (2004) „Rozmanitost jazyků a kultur v Rakousku-Uhersku a jejich konvergentní tendence." Comparative Cultural Studies in Central Europe. Brno. 11-42. Kurzová, Helena (1996) „Mitteleuropa als Sprachareal.“ V: Acta Universitatis Carolinae - Philologica 5, Germanistica Pragensia 13, 57-73.

7 Prim. Sowiński, Sławomir/Radosław Zenderowski (2003) Europa droga Koścuola. Jan Paweł II o Europie i europejskośći. Wrocław.

8 Prav tam, str. 36. 
tudi v prihodnje odprto in bo najverjetneje bolj kot splošno sprejeta teza tema abstraktnih teoretičnih diskurzov in ideologizirajočih interpretacij.

Fenomen t. i. srednje Evrope bo očitno tudi na prelomu 20. in 21. stoletja predmet permanentnega metakritičnega diskurza, ki bo vznemirjal publiciste, politologe, pa tudi literarne zgodovinarje, pisatelje in najrazličnejše umetnike. Zgodovine Evrope tudi kljub negativnim in bolečim konotacijam ni mogoče izbrisati iz kulturnega spomina ali nanjo pozabiti, lahko jo samo z občutkom in funkcionalno uporabljamo, povezujemo in razvezujemo, približujemo in oddaljujemo. Politične in administrativne metode delujejo uspešno, hitro in zanesljivo, vendar kratko, ekonomske so bolj stabilne, najbolj trdni in neuničljivi pa so kulturno-psihični arhetipi, ki so se ustvarjali skozi stoletja. Če je bila srednja Evropa kot duhovni in geografski prostor v svoji zgodovinski dimenziji vedno poskus ustvarjanja kulturnega ravnovesja med Zahodom in Vzhodom, nam ne preostane nič drugega, kot da tudi v prihodnosti upamo, da bodo razmišljanja o njeni podobi ne glede na politično realno alternativo dialoškega soobstoja primer tolerantnega sožitja in spoštovanja različnosti v enotnosti, predvsem pa mesto srečevanja in vzajemnega spoznavanja.

Prevedla Bojana Maltarič

\section{LITERATURA}

Andruchowycz, J., Środkowoschodnie rewizje, V: Andruchowycz, J. / Stasiuk. A., Moja Europa. Dwa eseje o Europie zwanej Środkowej, Wołowiec, 2001, str. 7-74.

Fejtö, F., Rekviem za mrtvou ř́ísi. O zkáze Rakouska-Uherska, Praha, 1998.

Funda, O. A., Znavená Evropa umírá, Praha, 2000.

Havel, V., Do různých stran. Eseje a články z let 1983-1989, Praha, 1990a.

Havel, V., Projevy (leden-červen 1990), Praha, 1990b. 
Horyna, B., Idea Evropy. Pohledy do filosofie dějin, Praha, 2001.

Kiš, D., Čas anatomije, Beograd, 1978.

Konrad, G., Antipolitik. Mitteleuropäische Meditationen, Frankfurt am Main, 1985.

Kontler, L., Dějiny Mad’arska. Úvahy o symbolické geografi, Praha, 2000.

Kos, J., Slovenska literatura in Srednja Evropa, Slavistična revija 38/1 (1990), str. 1-26.

Kroutvor, J., Potíže s dějinami, Praha, 1990.

Kundera, M., Únos Západu, 150000 slov 4, 10 (1985). V poljskem prevodu: Zachód porwany albo tragedia Europy środkowej, Zeszyty Literackie 1984, št. 5.

Kundera, M., L'art du roman. Paris, 1986.

Magris, C., Dunaj. Praha, 1992.

Magris, C., Habsburgský mýtus v moderní rakouské literatuře. Praha, 2001.

Molnár, G., Stredná Európa medzi federalizmom a katastrofou. Kultúra a súčasnost' 4, Zošity č. 9, Nitra, Katedra areálových kultúr, 2006.

Naumann, F., Mitteleuropa, Berlin, 1915.

Podiven, Češi v dějinách nové doby (1848-1939), Praha, 2003.

Šerlaimová, S., Slovanské literatúry v kontexte rakúsko-uhorskej štátnosti. V: Ďurišin, D. idr.: Osobitné medziliterárne spoločenstvá 5. Slovanské literatúry. Bratislava, 1993, str. 167-179.

Zatonski, D., Avstrijskaja literatura v XX stoletii. Moskva, 1985. 


\section{THE MYTH OF CENTRAL EUROPE IN THE EAST-WEST RELATIONS}

Keywords: myth, Central Europe, minimalist concept, maximalist
concept

\section{Abstract}

This paper studies different conceptions of Central Europe in the literary and historical discourse of the 20th century, and at the same time, compares how the concept of Central Europe is defined in the works of Havel, Kundera, Konrád and others. Central Europe has always been a cultural and geographical crossroads between the East and the West, with shifting centres and peripheries, overlapping ethnic groups, cultures and religions. For simplicity, two conceptions of Central Europe can be distinguished: minimalist and maximalist. The minimalist conception regards Central Europe as part of the West, because of analogous historical structures and cultural values. It partly overlaps the original Habsburg Empire and is opposed to the Balkans and Russia. The maximalist conception applies an axiological approach, regarding Central Europe as a set of historically established ideas, connected with the traditions of Christian civilisation, i.e. it includes the eastern and southern corners of Europe as well. Central Europe then is geographically identified with the symbolism of the Danube, as both a dividing and unifiying feature. According to Kundera, it is the Jewish people who have made the greatest contribution to the multicultural character of Central Europe, which after 1945 was politically aligned with the East, although historically it had been part of the West. 